\title{
CONTAMINANTS OF MEDICINAL HERBS AND HERBAL PRODUCTS
}

\author{
Ivan KOSALEC ${ }^{1}$, Josipa CVEK ${ }^{2}$, and Siniša TOMIĆ ${ }^{2}$ \\ Faculty of Pharmacy and Biochemistry, University of Zagreb ${ }^{1}$, Agency for Medicinal \\ Products and Medical Devices ${ }^{2}$, Zagreb, Croatia
}

Received in October 2009

Accepted in November 2009

\begin{abstract}
Medicinal plants have a long history of use in therapy throughout the world and still make an important part of traditional medicine. Thus, medicinal plants and herbal products must be safe for the patient (consumer). This review addresses biological contaminants (microbes and other organisms) and chemical contaminants (mycotoxins, toxic elements such as heavy metals, and pesticide residues) as major common contaminants of medicinal herbs and herbal products. To prevent and screen for contamination and ensure safety and conformity to quality standards, medicinal herbs and herbal products should be included in appropriate regulatory framework.
\end{abstract}

KEY WORDS: heavy metals, herbal medicines, microbes, mycotoxins, pesticides

Herbal products encompass a variety of selfprescribed preparations of plant origin that may generally be categorised as food, dietary supplements, cosmetics, and herbal medicinal products. The classification of herbal products is not aligned at either the European Union (EU) or global level, and remains under national competence. In addition to pharmacies, herbal products are widely available through other retail outlets, such as markets and mail order $(1,2)$.

The use of medicinal plants is perhaps the oldest method of coping with illnesses. Therefore, phytotherapy has been integrated into all systems of traditional medicine, often as the main source of healthcare in low- and middle-income countries. In recent decades, the use of herbal products has increased in developed countries, due in part to the widespread assumption that "natural" implies "harmless". However, with their popularity and global market expansion, the safety of herbal products has become a major concern in public health (3). Lack of regulation and loose distribution channels (including Internet sales) may result in adverse reactions attributable to the poor quality of herbal products. The most common causes are adulteration of herbal products with undeclared potent pharmaceutical substances, substitution or misidentification with toxic plant species, incorrect dosing, interactions with conventional medicines, and use of products contaminated with potentially hazardous substances, such as microbial metabolites (e.g. mycotoxins), radioactive particles, heavy metals, and agrochemical residues $(4,5)$. Many contaminants occur naturally in the ground and the atmosphere, such as radionuclides and metals. Some arise from past or present use of agents that pollute the environment and subsequently medicinal plants such as factory emissions or persistent chemical residues. Due to their excessive use and disposal, contaminants from environmental sources may even be present if an herb is organically grown (3). Harmful contaminants may also originate 
from the conditions in which the medicinal plants are cultivated, post-harvest treatment of herbal material (e.g. fumigants), and finished product manufacturing stages (e.g. organic solvent residues) (7).

Medicinal plants have a long history of use in therapy throughout the world and still make an important part of traditional medicine. Be it Ayurveda or Chinese, Unani or Tibetan, Amazonian or African, all systems of traditional medicine, integrate phytotherapy into their doctrines, even though they are based on different theoretical and cultural models (3). When we talk about the quality of medicinal plants we have in mind both their safety and efficacy. Several regulations setting high quality requirements for medicinal plants and related products on the market are shared at the global level in pharmacopoeias, while legal frameworks exist at the national or regional level. Figure 1 gives an overview of contamination and residues that can be found in medicinal herbs and herbal products. Even though medicinal herbs are widely used and perceived as safe, many compounds they contain can interact with synthetic drugs and many herbal preparations also have side effects $(8,9)$. This review however will not focus on them.

Instead, it will address biological contamination (with microbes and other organisms), and chemical contamination (with mycotoxins, toxic elements such as heavy metals, and pesticide residues) of medicinal herbs and herbal products, as the most common forms of contamination.

\section{BIOLOGICAL CONTAMINATION}

Biological contamination refers to impurities in medicinal herbs and their preparations and products, and may involve living microbes such as bacteria and their spores, yeasts and moulds, viruses, protozoa, insects (their eggs and larvae), and other organisms. However, products of microbial metabolism such as toxic, low-molecular-weight metabolites from moulds are chemical contaminants. Microbial contamination of herbs and/or products may result from improper handling during production and packaging. The most likely sources of contamination are microbes from the ground and processing facilities (contaminated air, microbes of human origin). Cross contamination is also possible from extraneous materials such as plastics, glass, and other materials which come in contact with medicinal herbs, herbal preparations or products. Hypothetically, sources of biological contamination could be human excrement, animal manure and faeces used as fertilizers. World Health Organization (WHO) contaminant guidelines (3)

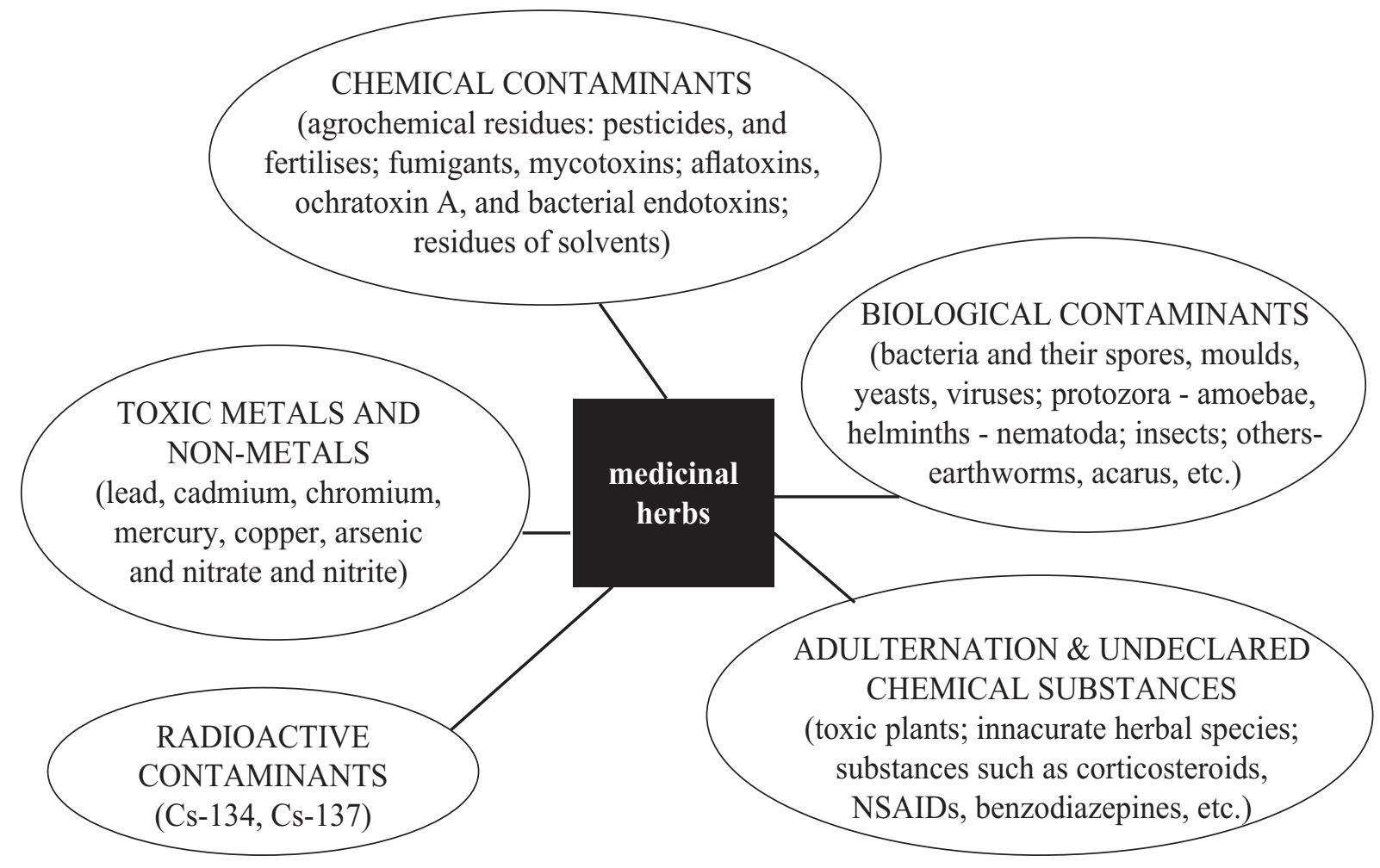

Figure 1 The most common contaminants of medicinal herbs 
propose that contamination should be avoided and controlled through quality assurance measures such as good agricultural and collection practices (GACP) for medicinal plants, and good manufacturing practices (GMP) for herbal medicines. Today, only a small percentage of medicinal plants are collected from the wild, and there are too few data to compare biological contamination between wild and cultivated medicinal herbs. Guidelines such as the GACP and GMP aim at reducing the overall risk of contamination, not only biological.

Aligned Pharmacopoeia chapters have been published on microbial limits or absence of specified microorganisms in herbal medicines (10). Total aerobic microbial count and total yeast and mould count [presented as colony-forming units per gram or millilitre (CFU g ${ }^{-1}$ or $\left.\mathrm{CFU} \mathrm{mL} \mathrm{mL}^{-1}\right)$ of raw herbal material or dosage forms], the absence of salmonellae, E. coli (or limited count) and Gram-negative bacterial species tolerant to bile have been used as indicators of microbiological quality (10). Table 1 shows the limits for different categories of microbiological quality of herbal medicinal products. Category A herbal medicinal products, which contain herbal drugs with or without excipients and are intended for preparation of infusions or decoctions with boiling water. This category includes traditionally brewed tea. Category $B$ includes extracts and/or herbal drugs pre-treated to reduce microbial contamination. If pre-treatment (processing or extraction with low strength alcohol or non-boiling water) does not meet Category B criteria of decontamination, the products falls in Category $\mathrm{C}$ (see Table 1).

Microbial count is just one of medicinal herb quality indicators. All products must be clear of true bacterial pathogens such as Salmonella spp., and Shigella spp..
An assessment of microbial contamination should take into account the following: route of application (in eyes, nose, respiratory tract); nature of the product (the presence of substrate which could promote the growth of microbes or preservatives); intended recipient (newborns, infants, debilitated patients); concomitant use of immunosuppressive agents and corticosteroids; underlying disease, wound, or organ damage (10).

Contamination of medicinal herbs and herbal products with bacterial strains resistant to known antibiotics poses a particular health risk. Brown and Jiang (11) studied the prevalence of antibioticresistant bacteria in twenty-nine herbal supplements purchased from local stores in the USA. They isolated the following resistant species: Bacillus spp., Erwinia spp., Ewingella americana, Staphylococcus spp., Enterobacter cloacae, and Stenotrophomonas maltophilia. The prevalence of antibiotic resistance was high to ampicillin, nalidixic acid, trimethoprim, ceftriaxone, and streptomycin. Opportunistic microbial species (bacteria and moulds) in teas can cause infection and pose a threat to immunosuppressed patients, especially those with AIDS. Kineman et al. (12) tested herbal products obtained from a national grocery store chain, from HIV-positive patients, and a local grocery cooperative, including purple cone-flower [Echinacea purpurea (L.) Moench], pepper (Piper methysticum G. Forst.), St. John's wort (Hypericum perforatum L.), and milk thistle [Silybum marianum (L.) Gaertn.] All products were contaminated with some of the following microbial species: Staphylococcus auricularis, Enterococcus casseliflavus, Enterobacter agglomerans, E. intermedius, Klebsiella pneumoniae, Sphingomonas paucimobilis; yeast Rhodotorula mucilaginosa, and the moulds Aspergillus niger

Table 1. Current limits for microbiological quality of medicinal herbs and herbal products according to the European Pharmacopoeia (since March 2009)

\begin{tabular}{lccccc}
\hline & TAMC & TYMC & E. coli & Salmonella spp. & BTGNB \\
\hline \multirow{2}{*}{ Category A } & $\begin{array}{c}10^{7} \\
\left(\max .5 \times 10^{7}\right)\end{array}$ & $\begin{array}{c}10^{5} \\
(\max .5 \times 105)\end{array}$ & $10^{3}$ & $\begin{array}{c}\text { Absence in } \\
\text { or CFU } \mathbf{~ m L}^{-1}\end{array}$ & NS \\
\hline \multirow{2}{*}{ Category B } & $10^{4}$ & $\begin{array}{c}10^{2} \\
\left(\max .5 \times 10^{4}\right)\end{array}$ & $\begin{array}{c}\text { Absence in } \\
1 \mathrm{~g} \mathrm{~mL}^{-1}\end{array}$ & $\begin{array}{c}\text { Absence in } \\
25 \mathrm{~g} \mathrm{~mL}^{-1}\end{array}$ & 102 \\
\hline \multirow{2}{*}{ Category C } & $10^{5}$ & $\begin{array}{c}10^{4} \\
\left(\max .5 \times 10^{5}\right)\end{array}$ & $\begin{array}{c}\text { Absence in } \\
1 \mathrm{~g} \mathrm{~mL}^{-1}\end{array}$ & $\begin{array}{c}\text { Absence in } \\
25 \mathrm{~g} \mathrm{~mL}^{-1}\end{array}$ & 104 \\
\hline
\end{tabular}

Legend: $T A M C=$ total aerobic microbial count; TYMC=total yeast and mould counts; $B T G N B=$ bile-tolerant Gram-negative bacteria; $C F U=$ colony-forming units; $N S=$ not set. 
(and other Aspergillus spp.) and Rhizopus spp. The authors made several suggestions as to how to improve the safety of herbal supplements in the immunocompromised population.

Antibiotic-resistant bacterial strains in medicinal teas used in hospitals could also be a source of infection. The method of brewing tea is important in decreasing bacterial count, and from the epidemiological point of view, is an important method of stopping the spread of hospital-acquired infections.

In 1997-1998, Acinetobacter baumannii was denounced as the source of an infection outbreak in a neurology intensive care unit (13). Hauer et al. (13) found a strain of $A$. baumannii in a tea infusion, but not in the tea leaves which were heavily contaminated with a wide range of other Gram-negative bacterial species. A. baumannii found in the hospital tap water was genetically the same as the one causing the infection. They inferred that contamination came from tap water mixed into the hot tea or itself insufficiently heated in an automatic water heater.

Wilson et al. (14) assessed the microbiological quality of fennel, chamomile, peppermint, and fruit teas (commercially available in tea bags). Some tea bags were brewed at $90{ }^{\circ} \mathrm{C}$ for 5 minutes according to the manufacturer's recommendations, and others were soaked in water taken from a hot-water outlet of an automatic coffee machine (temperature $67^{\circ} \mathrm{C}$ ) of a bone marrow transplantation ward. At $90{ }^{\circ} \mathrm{C}$, all the examined teas (infusions) were contaminated with non-fermentative Gram-negative bacterial species, while spore-forming bacteria were most prominent in chamomile and peppermint teabags teas. High temperature $\left(90^{\circ} \mathrm{C}\right)$ decreased the number of moulds in teas. However, in the second group of teas, $67^{\circ} \mathrm{C}$ was not enough to kill the bacteria and the total microbial count of aerobic microbes ranged between $3.8 \times 10^{3} \mathrm{CFU} \mathrm{mL}^{-1}$ and $1.6 \times 10^{6} \mathrm{CFU} \mathrm{mL}^{-1}(14)$.

A study by Wilson et al. (14) showed a significant growth of A. baumannii, E. coli, E. faecalis, and $P$. aeruginosa species in fennel and chamomile teas. A. baumannii species increased from $10^{3} \mathrm{CFU} \mathrm{mL}^{-1}$ to $10^{5} \mathrm{CFU} \mathrm{mL} \mathrm{m}^{-1}$ in chamomile tea within $6 \mathrm{~h}$ and to $10^{8} \mathrm{CFU} \mathrm{mL} \mathrm{m}^{-1}$ within $24 \mathrm{~h}$ of preparation. The results were similar for peppermint tea, with the exception of $E$. coli, which showed hardly any increase within 24 h. S. aureus count decreased consistently after 6 $\mathrm{h}$ from $1.1 \times 10^{3} \mathrm{CFU} \mathrm{mL} \mathrm{mL}^{-1}$ to less than $27 \mathrm{CFU} \mathrm{mL}^{-1}$ in the remaining $18 \mathrm{~h}$ (14). This suggests that the teas used in the hospital were a good substrate for microbial growth. An essential step in lowering the microbial count was brewing and even more brewing time, because pathogenic microbes can survive $90{ }^{\circ} \mathrm{C}$ for a short while.

Products contaminated with Clostridium spp. spores such as honey $(15,16)$ and medicinal herbs are not recommend for infants younger than one year of age. Because the spores of Clostridium botulinum could cause infant botulism, the use of home-prepared teas as a natural remedy against intestinal colic must be avoided in children younger than one year. In a study by Bianco et al. (17), $7.5 \%$ of 200 chamomile (Matricaria recutita L.) tea samples were contaminated with the spores of $C$. botulinum. Botulinum spores were significantly more prevalent in chamomile sold by weight in herbal stores (unwrapped chamomile) than in chamomile tea sold in tea bags. The spore-load was 0.3 to 0.4 spores per gram of chamomile, and they found $C$. botulinum types A, B, and $\mathrm{F}$ in $53.3 \%$, $6.7 \%$, and $13.3 \%$ of positive samples, respectively. The authors concluded that ingestion of chamomile tea could involve a risk of infant botulism.

Clostridium spores could also be expected in other medicinal herbs. Very high contamination was documented by Martins et al. (18); C. perfringens spores were found in $83.9 \%$ of investigated herbal samples, but only $19.2 \%$ had levels above $10^{3}$ spores per gram. Corn silk (Zea mays L.), linden tree flowers (Tilia platyphyllos Scop.), and orange tree leaves (Citrus sinensis (L.) Osbeck) were highly contaminated with $C$. perfringens spores, while 8 of 13 chamomile samples were contaminated with C. botulinum spores. Spores of Bacillus cereus, also responsible for food-borne toxoinfection were found in $96.8 \%$ of the samples, with $60 \%$ of samples having levels higher than $10^{3}$ spores per gram (18).

Contamination of medicinal herbs with true microbial pathogens such as Salmonella spp., Shigella spp., Listeria monocytogenes, and Vibrio spp. is rarely documented. However, an infection with the Salmonella enterica serovar Agona from contaminated herbal tea bags containing aniseed (Pimpinella anisum L.), fennel (Foeniculum vulgare Mill.), and caraway (Carum carvi L.) that broke out among infants under the age of 13 months in Germany from October 2002 to July 2003 (19) put in the spotlight the need for rigid microbiological quality control of medicinal herbs and herbal preparations.

Because they are widespread in the atmosphere, moulds are common natural contaminants of medicinal herbs. Some authors found that aerial herbal parts (leaves, herb) had higher levels of mould 
contamination. In a study of 91 medicinal herb samples in Brazil, Bugno et al. (21) found that $50 \%$ of aerial part samples were contaminated with fungi, followed by flower samples (16\%). Similar results were published from a study of 85 Croatian and imported herbal drugs (53 herbal species) by Cvetnić and Pepeljnjak (22), who found that herbs, rhizomes, and roots were highly contaminated with moulds.

In contrast to moulds, which are potent allergens and producers of mycotoxins, little is known about yeast species in medicinal herbs and herbal products. In a survey of microbiological contamination of medicinal herbs collected from a public market in Lisbon (Portugal), Martins et al. (18) found the yeast Rhodothorula glutinis in $7.7 \%, 15.4 \%$, and $100.0 \%$ of chamomile, linden flower, and pennyroyal mint samples, respectively. $R$. mucilaginosa was more frequent in chamomile and orange tree leaves. They also identified yeast species such as Cryptoccocus laurentii in chamomile and Cryptococcus albidus in chamomile and in corn silk. Candida guilliermondii, Kloeckera japonica, and Saccharomyces cerevisiae were also identified, but their prevalence was low. Similar results were found in a study of medicinal herbs from the Croatian market by Halt and Klepec (20), where yeasts from the genus Saccharomyces and Candida were the most prevalent. As all these microbes could act as opportunistic pathogens, herbal products are to be administered to immunodeficient patients with great caution.

Fungal contamination brings a risk of mycotoxin contamination of medicinal herbs as a raw material. To prevent biological contamination of medicinal herbs, some post-harvesting procedures are applied such as natural drying or decontamination. Ethylene oxide has been prohibited for decontamination of herbal substances in Europe since 31 December 1989 (23). One of the widely used fumigants, methyl bromide, is currently being phased out worldwide in accordance with the 1992 Montreal Protocol, as it depletes ozone $(24,25)$. Alternative measures for pest control of herbal substances should rely on GACP and GMP.

To avoid microbial growth and toxin production in situ, it is possible to decrease microbial count in raw herbal material using gamma-irradiation. However, does gamma-irradiation affect the quality of medicinal herbs? Mishra et al. (26) found no quality changes in green tea leaves [Camellia sinensis (L.) Kuntze] irradiated at $5 \mathrm{kGy}$, including no significant effect on total phenolics. At $10 \mathrm{kGy}$, irradiation did not affect the antioxidant and biological properties of tea such as free radical scavenging activity, inhibition of xanthine oxidase and lipid peroxidation, and superoxide and nitrite scavenging activities. Antimicrobial and sensory properties also remained unaffected (26). Similar results were documented by Furgeri et al. (27), who found no changes in phenolic compounds of maté leaves (Ilex paraguariensis A. St. -Hil.) gamma-irradiated by doses of up to $10 \mathrm{kGy}$. Irradiation of liquorice roots (Glycyrrhiza glabra L.) with ${ }^{60} \mathrm{Co}$ at doses of up to $20 \mathrm{kGy}$ did not change the sensory parameters (colour, flavour, texture, and taste) of the liquorice solution (28). However, the authors found that concentrations of mineral ions $(\mathrm{Na}, \mathrm{Ca}$, and $\mathrm{K}$ ) were lower than in non-irradiated solutions while glycyrrhezinic acid and maltose concentration were higher (28). Similar results were published by Gašpar Randić et al. (29), who gamma-irradiated marshmallow roots (Althaea officinalis L.) by doses of up to $10 \mathrm{kGy}$, and found no differences in the aminoacid profile between irradiated and non-irradiated samples.

An et al. (30) demonstrated that irradiation did not affect the biological activity green tea polyphenols, and even increased their anti-microbial activity. Their results also showed that irradiation removed dark colouration from the leaves, and that it may be applicable in food or cosmetic industries. Similar results were published by Jo et al. (31), who showed that irradiation enhanced the colour of green tea leaf extracts without any adverse changes in DPPH radical scavenging and tyrosinase inhibition. However, the EU does not allow irradiation of medicinal herbs and there are methods such as pulsed photostimulated luminescence, thermoluminiscence or electron spin resonance spectroscopy to check whether a herb has been irradiated before it has been marketed in the EU.

Drying at high temperature decreases the total aerobic microbial count (TAMC) in herbs such as milk thistle [Silybum marianum (L.) Gaertn.]. TAMC dropped from $4.55 \times 10^{8} \mathrm{CFU} \mathrm{g}^{-1}$ at $40{ }^{\circ} \mathrm{C}$ to $1.5 \times 10^{5} \mathrm{CFU} \mathrm{g}^{-1}$ at $100{ }^{\circ} \mathrm{C}$, while the content of sylimarin increased from $2.86 \%$ at $40{ }^{\circ} \mathrm{C}$ to $3.31 \%$ at $100{ }^{\circ} \mathrm{C}(32)$. Iguera (32) has given a nice overview of control measures to prevent microbial contamination. These include avoiding harvesting or collection in damp and cool weather; avoiding contact between fresh herbs and soil; avoiding outdoor drying facilities; observing appropriate drying and storage procedures, and assessing the potential sources of risk.

In addition to microbial contamination, medicinal plants could be infested with insects and their eggs 
and larvae. Cosmopolitan insects that infest medicinal herbs include Indian meal moth (Plodia spp.), cacao moth (Ephestia spp.), flour beetle (Tribolium spp.), rice weevil (Sitophilus spp.), merchant grain beetle (Oryzaephilus spp.), lesser grain borer (Rhyzopertha spp.), and khapra beetle (Trogoderma spp.) (32). These infestations are sometimes treated with $\mathrm{CO}_{2}$ (33), but proper control should include general measures such as protecting raw materials from high temperatures $\left(>25^{\circ} \mathrm{C}\right)$ and maintaining warehouse cleanliness, proper storing of herbal material, and educating warehouse staff.

Arbogast et al. (34) studied the infestation of stored dried saw palmetto berries [Serenoa repens (W. Bartram) Small] and dried passion-flower (maypop) vines (Passiflora incarnata L.). The measures they proposed to control infestation included i) warehouse monitoring with pheromone-baited sticky traps to precisely determine the foci of infestation; ii) removing debris from cleaning operations to prevent insect breeding; and iii) maintaining sanitary standards in the warehouse by thorough cleaning and fumigation with phosphine under a tarpaulin (34).

Medicinal herbs and herbal products are rarely reported as sources of viral contamination. However, there was a report of acute hepatitis E (immunoserologically diagnosed) in Japan, associated with a traditional Chinese medicinal product (35).

\section{CHEMICAL CONTAMINATION}

\section{Mycotoxins}

As some secondary metabolites produced by moulds could be toxic to humans, the European legislation has set maximum levels of mycotoxins (aflatoxin $B_{1}$ and sum of $B_{1}, B_{2}, G_{1}$ and $G_{2}$ ) for a variety of foostuffs and spices such as sweet pepper (Capsicum L. spp.), pepper (Piper L. spp.), nutmeg (Myristica fragrans Houtt.), turmeric (Curcuma longa L.), and ginger (Zingiber officinale Roscoe) (36). Recently, the European Pharmacopeia (38) (Chapter 2.8.18). provided test methods and has set limits for aflatoxin $1\left(2 \mu \mathrm{g} \mathrm{mL}^{-1}\right)$ and the sum of $B_{1}, B_{2}, G_{1}$, and $\mathrm{G}_{2}$ aflatoxins $\left(4 \mu \mathrm{g} \mathrm{mL}^{-1}\right)$ for some medicinal herbs. A limit of $20 \mu \mathrm{g} \mathrm{kg}^{-1}$ for ochratoxin A (OTA) (Chapter 2.8.22.) has also been adopted for liquorice root (Glycyrrhiza glabra L.).

A study of medicinal herbs collected from a Brazilian market (21) showed that more than $50 \%$ of samples exceeded the microbial count limits set by the US Pharmacopoeia. The highest mould burden was observed in leaves, followed by flowers, rhizomes, roots, barks, and seeds. Dominant moulds were from the Aspergillus genus, followed by Penicillium genus. Most aspergilla isolates were potentially mycotoxic and included: A. flavus, A. parasiticus, $A$. ochraceus, A. niger and A. fumigatus. Other mould genera included Alternaria spp., Chaetomium spp., Cladosporium spp., Mucor spp., Rhizopus spp., Paellomcyes spp., Phoma spp., and Trichoderma spp. (21). After the testing for mycotoxin-producing abilities under in vitro conditions, $21.97 \%$ isolates were found to produce mycotoxins, of which $42.9 \%$ aflatoxin, $22.4 \%$ ochratoxin, and $34.7 \%$ citrinin (21). In the study by Cvetnić and Pepeljnjak (22), the most prevalent mould isolates in medicinal herbs were Aspergillus spp., Penicillium spp. and Mucor spp. Among aspergilla isolates, the most common were Aspergillus glaucus, A. flavus, and A. niger group. The aflatoxigenicity of Aspergillus spp. isolates was very low [only 1 in 15 isolates from gentian roots (Gentiana lutea $\mathrm{L}$.) produced aflatoxin $\left.\mathrm{B}_{1}\right]$.

Mould mycotoxin production depends on several factors including: genetic predisposition of the mould to produce mycotoxins, substrate, humidity, $\mathrm{CO}_{2}$ : $\mathrm{O}_{2}$ ratio, and the presence of fungicides or other competitive microbial species. As for the chemical profile of substrates, some medicinal herbs contain essential oils which act as natural antimicrobials and may inhibit mould development and mycotoxin production (39). MacDonald and Caste (40) found that, even though aflatoxin-producing mould species Aspergillus flavus grows well on spices, they produce less aflatoxin $B_{1}$ on spices than on cereals. Fuat Abd Razak et al. (41) also concluded that powdered mixed herbal drugs had an inhibitory effect on the growth of fungi.

Moulds of the Aspergillus and Penicillium genera seem to be the most common contaminants of raw medicinal herbs $(21,41)$. Some strains of the A. flavus and $A$. parasiticus species produce aflatoxin $\mathrm{B}_{1}$, and not all strains of $A$. ochraceus and $A$. niger produce OTA. Bugno et al. (21) found that not all isolates of the Aspergillus and Penicillum genus, otherwise known as mycotoxin producers, produce mycotoxins under in vitro conditions or in raw herbal materials. For example, 16 of 58 strains of Aspergillus flavus produced aflatoxin $\mathrm{B}_{1}$ or aflatoxin $\mathrm{B}_{1}$ and $\mathrm{B}_{2}$, while only 2 of $52 \mathrm{~A}$. niger strains produced ochratoxin. Nearly $22 \%$ of the Aspergillus and Penicillium 
isolates produced mycotoxins in vitro. Romagnoli et al. (40) studied aflatoxin $B_{1}$ contamination in different kinds of spices, aromatic herbs, and medicinal plants randomly collected from public markets, supermarkets and shops in Emilia Romagna (Italy). Interestingly, they did not find aflatoxin $B_{1}$ in 48 of 103 samples. Aflatoxin $\mathrm{B}_{1}$ was confirmed in five samples of chilli pepper (whole or crushed; $11 \%$ of all spices tested), and one sample showed the presence of aflatoxins $\mathrm{B}_{2}, \mathrm{G}_{1}$, and $\mathrm{G}_{2}$.

Microbiological and mycotoxicological quality assessment of medicinal herbs should include mycotoxin contamination, especially of the parts at higher risk of contamination or herbs from hot and humid climates (39).

According to the International Agency for Research on Cancer (IARC), OTA is carcinogenic (class 2B) (42). It is also nephrotoxic, teratogenic, immunotoxic, and associated with nephropathy in humans. OTA is a secondary low-molecular-weight metabolite of some fungal species, notably Penicillium verrucosum and Aspergillus ochraceus, but A. carbonarius and A. niger can also produce OTA. All of these mould species can contaminate medicinal herbs with OTA. OTA contaminates foodstuff such as cereals, coffee, dried fruit, grapes, cocoa, wine, beer, spices, and can occur as a residue in animal products such as pork meat and kidneys $(43,44)$.

It seems that liquorice roots (rhizoma) favour contamination with OTA-producing moulds. Bresch et al. (45) detected OTA in $50 \%$ of liquorice root samples (OTA mass fraction from $0.3 \mathrm{ng} \mathrm{g}^{-1}$ to 216 $n \mathrm{ng}^{-1}$ ), while Majerus et al. (46) detected OTA in all investigated samples of liquorice roots and products (sweets, botanicals). Ariño et al. (47) confirmed early results of OTA contamination of liquorice roots and products (sweets, liquid extracts, solid blocks). They investigated 30 liquorice roots and products using liquid chromatography - fluorescence detection (LC-FLD), and the highest concentration of OTA was found in dry liquorice root samples [mean \pm S.E. $=(63.6 \pm 20.8) \mathrm{ng} \mathrm{g}^{-1}$, range $1.4 \mathrm{ng} \mathrm{g}^{-1}$ to $252.8 \mathrm{ng} \mathrm{g}^{-1}$. However, only a small part of OTA was transferred to tea the authors made of them $(5 \%$ by decoction and $3 \%$ by infusion with hot water) $(47,48)$.

Fumonisins are mainly produced by Fusarium verticillioides $(=F$. moniliforme) and by $F$. proliferatum, and the most abundant is fumonisin $\mathrm{B}_{1}\left(\mathrm{FB}_{1}\right)$, which is carcinogenic, according to IARC (class 2B ) (49). It is common in maize and maize products.
Only a few studies investigated $\mathrm{FB}_{1}$ contamination of medicinal herbs and herbal products. Omurtag and Yazicioğlu (50) used HPLC to analyse 115 commercially available herbal tea and medicinal plant samples. They detected $\mathrm{FB}_{1}$ in only two tea samples (0.160 $\mathrm{ng} \mathrm{g}^{-1}$ and $1.487 \mu \mathrm{g} \mathrm{g}^{-1}$, respectively), and $\mathrm{FB}_{2}$ in none of the samples were also contaminated with $\mathrm{FB}_{1}$ (18). Martins et al. (18) detected FB in 55 (65.5\%) of the 87 samples herb samples from Portugal Black tea had the highest rate of positive samples $(88.8 \%)$ (FB 1 mass fraction from $80 \mu \mathrm{g} \mathrm{kg}^{-1}$ to $280 \mu \mathrm{g} \mathrm{kg}^{-1}$ ). In respect to the medicinal plants, orange tree leaves had higher FB levels (from $350 \mu \mathrm{g} \mathrm{kg}^{-1}$ to $700 \mu \mathrm{g}$ $\mathrm{kg}^{-1}$ ), followed by linden tree leaves and flowers (from $20 \mu \mathrm{g} \mathrm{kg}^{-1}$ to $200 \mu \mathrm{g} \mathrm{kg}^{-1}$ ). Corn silk and chamomile were less contaminated with $\mathrm{FB}_{1}$, whose mass fractions ranged from $50 \mu \mathrm{g} \mathrm{kg}^{-1}$ to $150 \mu \mathrm{g} \mathrm{kg}^{-1}$ and from $20 \mu \mathrm{g} \mathrm{kg}^{-1}$ to $70 \mu \mathrm{g} \mathrm{kg}^{-1}$, respectively. None of the samples was contaminated with $\mathrm{FB}_{2}$. Medicinal herbs collected in the wilderness of the South African province of Eastern Cape also contained $\mathrm{FB}_{1}$ ( 8 of 30 samples were positive) at levels ranging from $8 \mu \mathrm{g} \mathrm{kg}^{-1}$ to $1533 \mu \mathrm{g} \mathrm{kg}^{-1}$ (51). The authors concluded that $\mathrm{FB}_{1}$ contamination was much more widespread in South Africa'n medicinal herbs than initially thought.

Using enzyme-linked immunosorbant assay (ELISA), Santos et al. (52) found that of the 84 medicinal herb samples collected in Spain, $99 \%$ were contaminated with T-2, $98 \%$ with ZEA, $96 \%$ with AFs, $63 \%$ with OTA, $62 \%$ with DON, $61 \%$ with citrinin, and $13 \%$ with FBs. All samples were contaminated with several mycotoxins. Nearly $87 \%$ were contaminated with a combination of four or more mycotoxins. AFs, T-2, and ZEA were the dominant combination.. This was the first study to report such a high co-contamination rate.

\section{Toxic elements}

Metals are widely distributed throughout nature and occur freely in soil and water. As they are likely to be present in many foods, it is important to reduce the total population exposure to toxic elements by minimising contamination of herbal products $(3,53)$. But limits for toxic elements in herbal products are yet to be set at the global level. However, the European Pharmacopoeia has issued a draft monograph Herbal drugs (54), proposing the following limits for heavy metals in herbal drugs: $5 \mathrm{mg} \mathrm{kg}^{-1}$ for lead, $0.5 \mathrm{mg} \mathrm{kg}^{-1}$ for cadmium, and $0.1 \mathrm{mg} \mathrm{kg}^{-1}$ for mercury. Furthermore, the European Commission has established the lead, cadmium, and mercury limits in 
Table 2 Examples of national and regional limits $\left(\mathrm{mg} \mathrm{kg}^{-1}\right)$ for arsenic and toxic metals in herbal products

\begin{tabular}{|c|c|c|c|c|c|c|c|c|}
\hline & & As & $\mathbf{P b}$ & Cd & $\mathrm{Cr}$ & Hg & $\mathrm{Cu}$ & $\begin{array}{c}\text { Total as } \\
\mathbf{P b}\end{array}$ \\
\hline & HD & 5 & 10 & 0.3 & 2 & 0.2 & & \\
\hline Canada & $\begin{array}{c}\text { HP } \\
\left(\mathrm{mg} \mathrm{day}^{-1}\right)\end{array}$ & 0.01 & 0.02 & 0.006 & 0.02 & 0.02 & & \\
\hline China & HD & 2 & 10 & 1 & & 0.5 & & 20 \\
\hline Malaysia & $\mathrm{HP}$ & 5 & 10 & & & 0.5 & & \\
\hline Republic of Korea & HD & & & & & & & 30 \\
\hline Singapore & HP & 5 & 20 & & & 0.5 & 150 & \\
\hline Thailand & $\mathrm{HD}, \mathrm{HP}$ & 4 & 10 & 0.3 & & & & \\
\hline WHO & HD & & 10 & 0.3 & & & & \\
\hline $\begin{array}{l}\text { United States } \\
\text { Pharmacopoeia } \\
\text { (USP) }\end{array}$ & $\mathrm{HE}$ & & & & & & & 20 \\
\hline $\begin{array}{l}\text { Italian } \\
\text { Pharmacopoeia } \\
\text { (FUI) }\end{array}$ & HD & & 3 & 0.5 & & 0.3 & & \\
\hline $\begin{array}{l}\text { Ph. Eur. draft } \\
\text { monograph Herbal } \\
\text { drugs (54) }\end{array}$ & HD & & 5 & 0.5 & & 0.1 & & \\
\hline $\begin{array}{l}\text { Regulation (EC) } \\
629 / 2008\end{array}$ & FS & & 3 & $\begin{array}{c}1 \\
\text { (3 for } \\
\text { seaweed } \\
\text { products) }\end{array}$ & & 0.1 & & \\
\hline
\end{tabular}

Legend: USP - United States Pharmacopoeia $29^{\text {th }}$ revision and the National Formulary $24^{\text {th }}$ edition, 2006; FUI - Farmacopea Ufficiale della Repubblica Italiana, $11^{\text {th }}$ edition, 2002; HD - crude herbal drugs; HP - finished herbal products; HE - herbal extracts; FS - food supplements.

food supplements (55), that have been in force since 1 July 2009. Table 2 shows national and regional limits for arsenic and toxic metals in various types of herbal products proposed by the WHO (3).

The maximum amounts of metals in medicinal plant materials can also be given based on the provisional tolerable intake (PTI) values established by the World Health Organization WHO and the Food and Agriculture Organization (FAO). Thay have also jointly proposed acceptable levels of toxic substances that can be ingested on a weekly basis, so called the Provisional Tolerable Weekly Intake (PTWI). PTWI is generally used for contaminants that may accumulate in the body, and the weekly designation is used to stress the importance of limiting intake over a period of time for such substances (56). PTWI has been proposed for mercury $\left(5 \mu \mathrm{g} \mathrm{kg}^{-1}\right.$ b.w.), arsenic (15 $\mu \mathrm{g} \mathrm{kg}^{-1}$ b.w.), lead $\left(25 \mu \mathrm{g} \mathrm{kg}^{-1}\right.$ b.w.), and cadmium (7 $\mu \mathrm{g} \mathrm{kg}^{-1}$ b.w.), as the major toxic elements (57-60). Lead and mercury, for instance, can cross the placental barrier with potential toxic effects on the foetus (61).
While all metals are toxic at some level of exposure (Table 3), many metals have important biological roles and thus are considered essential for good health. For example, zinc is a cofactor for more than 100 metalloenzymes and its deficiency can have numerous adverse effects on normal growth and development, reproduction, and immune function. Nevertheless, at sufficient concentrations, a number of these essential metals are potentially toxic $(62,63)$.

Provisional Maximum Tolerable Daily Intake (PMTDI) is the endpoint used for contaminants with no cumulative properties. It stands for permissible human exposure to substances naturally occurring in food and drinking water. Trace elements, which are essential nutrients and unavoidable constituents of food, are expressed by a range, with the lower end is the minimum daily dietary requirement and the upper end the daily limit (56). The range for copper is $0.05 \mathrm{mg} \mathrm{kg}^{-1}$ b.w. to $0.5 \mathrm{mg} \mathrm{kg}^{-1}$ b.w. and for zinc $0.3 \mathrm{mg} \mathrm{kg}^{-1}$ b.w. to $1 \mathrm{mg} \mathrm{kg}^{-1}(64)$. 
Table 3 Common uses and principal toxic effects of arsenic and selected metals (62)

\begin{tabular}{lll}
\hline Element & Common Industrial Uses & Principal Toxic Effects \\
\hline Arsenic & Pesticides, herbicides & Lung cancer, skin diseases \\
\hline Cadmium & Batteries, plastics, pigments, plating & Kidney damage, lung cancer, bone disorder \\
\hline Chromium & Plating, alloys, dyes, tanning & Respiratory effects, allergic dermatitis \\
\hline Lead & Batteries, wire and cable, alloys & $\begin{array}{l}\text { Neurological effects, haematopoietic system } \\
\text { damage, reproductive effects }\end{array}$ \\
\hline Manganese & Pesticides, ceramics, batteries, steel & Central nervous system effects \\
\hline Mercury & $\begin{array}{l}\text { Chloroalkali industry, pesticides, } \\
\text { thermometers, batteries }\end{array}$ & Neurological effects, kidney damage \\
\hline Nickel & Coins, jewellery, alloys, plating, batteries & Dermatitis \\
\hline Thallium & Electronics, alloys & $\begin{array}{l}\text { Neurological, heart, lung, kidney, and liver } \\
\text { effects }\end{array}$ \\
\hline Zinc & $\begin{array}{l}\text { Batteries, alloys, galvanizing, dyes, } \\
\text { pharmaceuticals }\end{array}$ & Gastrointestinal effects, anaemia \\
\hline
\end{tabular}

The need for inclusion of tests for toxic elements and acceptance criteria should be studied at the various developmental stages of the plant and based on knowledge of the medicinal plant species, its growth or cultivation and the manufacturing process. Jyoti et al. (65) reported that contamination of medicinal plants with lead, cadmium, chromium, and nickel varied between plant species, even though they shared the same environment. Furthermore, heavy metal content in the same medicinal plant differed from one collection site to another in the same city; it was lower in residential areas than in heavy traffic areas. These results confirmed the well-known fact that soil is not the only source of heavy metals. Bioaccumulation can also be influenced by genetic predisposition of a given species, period/season of sampling, plant part, and other geoclimatic factors (66). For herbal drugs known to accumulate toxic metals, the European Pharmacopoeia (67) has set the following limits: $0.5 \mathrm{mg} \mathrm{kg}^{-1}$ for cadmium in linseed (Lini semen; species Linum usitatissimum L.) and $90 \mathrm{mg} \mathrm{kg}^{-1}$ for arsenic, $4 \mathrm{mg} \mathrm{kg}^{-1}$ for cadmium, $5 \mathrm{mg} \mathrm{kg}^{-1}$ for lead and $0.1 \mathrm{mg} \mathrm{kg}^{-1}$ for mercury in the thallus of kelp (Fucus vel Ascophyllum; species: Fucus vesiculosus L., F. serratus L., Ascophyllum nodosum Le Jolis). The limit for arsenic in kelp is relatively high, because its organic form is believed not to absorb via the gastrointestinal tract.

Man-made environmental pollution can largely affect heavy metal contamination levels of herbal materials. It includes emissions from factories, leaded petrol, agrochemicals such as cadmium-containing fertilizers, organic mercury, and arsenic-based pesticides that are still in use in some countries (3). In general, if the heavy metal burden of herbal material is unknown, it is suggested that it be determined in several batches, preferably collected over a period of several years. Based on retrospective data, it is possible to establish acceptable limits such as those presented in a recent evaluation by Gasser et al. (68). Limits should take into account that herbal drugs are mainly consumed processed. Therefore, appropriate exposure assessment should identify the chemical form of the dissolved part of the toxic element in herbal extracts and its bioavailability. A group of Bulgarian and Turkish authors studied the content of arsenic, cadmium, and lead in commonly used herbal teas and their aquatic infusions (69). Lead was found to be virtually water insoluble, although its concentration in herbal materials was higher than that of arsenic and cadmium. The extraction efficiency of arsenic (12\% to $61 \%$ ) and cadmium (9\% to $74 \%$ ) varied by plant species. Fractionation showed that most of the arsenic and lead in herbal infusions was bound to biomacromolecules. The authors believe that these macromolecules are large polyphenolic compounds ubiquitous in the plant kingdom. They have also assumed that arsenic and lead from herbal infusions are virtually not bioavailable because they resorb poorly, and are therefore less toxic (69).

Herbal products can be contaminated at any stage of production, from growing conditions to open-air drying, preserving, and manufacturing (e.g. release from lead-containing utensils) $(7,70)$. Furthermore, metals are sometimes intentionally added to Asian herbal preparations, because the traditional Indian (Ayurvedic) and Chinese medicine believe in their therapeutic properties $(71,72)$. Therefore, it is not 
uncommon to find excessive quantities of toxic elements in such formulations $(53,70,73-75)$. Moreover, lead, thallium, mercury, arsenic, gold, copper, and cadmium poisoning from consumption of these products have been reported on a number of occasions $(72,76-80)$.

Non-Asian herbal products, such as those from Africa (81, 63), Europe (82, 83), South America $(61,84)$, and Mexico (85) have also been reported to contain high concentrations of toxic elements and pose a serious health risk. For example, a Brazilian study (61) revealed that the estimated lead intake through horse chestnut reached $440 \%$ of the PTWI value, which would significantly increase body lead burden if the product were taken on a long-term basis. A publication on Nigerian herbal remedies reported that all analysed samples contained levels of iron, nickel, cadmium, copper, lead, selenium, and zinc that would exceed the allowable daily intake if taken as recommended. $96 \%$ of the remedies tested gave a daily dose of lead in excess of $514 \mu \mathrm{g}$, which is higher than lead PTWI set by FAO/WHO ( $25 \mu \mathrm{g}$ $\mathrm{kg}^{-1}$ b.w., corresponding to $250 \mu \mathrm{g}$ per day for a $70 \mathrm{~kg}$ person). The authors expressed concern that the metal constituents of the remedy could cause a variety of ailments in the Nigerian population due to their widespread and prolonged use (63).

\section{Pesticide residues}

Pesticides are chemical compounds used to control or eradicate pests. Based on intended use, they are grouped as insecticides, fungicides, nematocides, herbicides, rodenticides, and others (e.g. ascaricides, molluscicides) (86). According to chemical structure, they are grouped as organochlorine pesticides (OCPs) [hexachlorocyclohexanes $(\mathrm{HCH})$ or benzene hexachlorides (BHC), lindane, dichlorodiphenyl trichloroethane (DDT)]; organophosphorus pesticides (OPs) [chlorpyrifos and methylchlorpyrifos, coumaphos, dichlorvos, ethion, fenchlorphos (fenclofos), malathion, parathion], nitrogen-containing pesticides (such as atrazin, simazin, or propazin), pesticides of plant origin (pyrethroids and rotenoids), etc.

While OCPs were widely used in agricultural and malaria control programs in the mid $20^{\text {th }}$ century, their use has been almost completely discontinued due to adverse health effects. Lipophilicity and slow degradation make them persist in the environment and accumulate in the food chain. Furthermore, this group of pesticides (e.g. DDT) accumulates in adipose tissue and is a latent threat to health (87). The main adverse effects associated with overexposure to OPs are symptoms of the nervous system, including headache, dizziness, paraesthesia, tremor, discoordination, or convulsions (86).

Because they are lipophilic, OPs are readily absorbed through ingestion, skin, or inhalation. They have a relatively short half-life and are rapidly metabolised and excreted. They inhibit the enzyme acetylcholinesterase at its ester site, which in turn leads to the accumulation of neurotransmitter acetylcholine in the nerve tissue and at the effector organ, and to continued stimulation of cholinergic synapses. Delayed neuropathy is the main chronic effect of exposure to OPs (86). Delayed, predominantly motor peripheral neuropathy, also known as ginger jake paralysis, was reported in the United States in the 1930s in people drinking ginger liquor contaminated with tri-ortho-cresyl-phosphate (TOCP) in the United States in the 1930s.

Some compounds with insecticidal properties can be found in nature, such as pyrethrin extract from the chrysanthemum flower [Tanacetum cinerariifolium (Trevir.) Sch. Bip.]. These compounds are highly fat soluble, but are easily degraded and excreted in humans. This is why synthetic pyrethroids have been developed, with better stability to light and heat. The activity sites of pyrethroids are voltage-dependent sodium channels in the nerves. By slowing the closing of the sodium activation gate, they cause prolonged depolarisation of the nerve, and block the impulse. Pyrethroids, just like pyrethrins, do not bioaccumulate in humans. Due to greater insecticidal activity and lower toxicity in mammals, pyrethroids are gradually replacing organochlorides and organophosphates as pesticides of choice (86).

Only OCPs (e.g. HCH) and a few OPs (e.g. carbophenothion) have long residual action (3). The term "pesticide residues" means residues of active substances, including their metabolites and/or degradation products, currently or formerly used in plant protection products (88). Although the use of many persistent pesticides has been banned in many countries for years, residues may still remain in the environment due to low biodegradability (89). Chlorinated pesticide residues in raw herbal materials seem to be quite common $(90,91)$. Because of general environmental pollution, even organically raised crops are not necessarily pesticide-free (92). In some developing countries, many of these substances are still used for public health purposes, for example to 
Table 4 Examples of limits $\left(\mathrm{mg} \mathrm{kg}^{-1}\right)$ for some pesticide residues in medicinal plant materials (Ph. Eur., USP) and spices [Codex Alimentarius Commission (3)].

\begin{tabular}{|c|c|c|}
\hline \multirow[b]{2}{*}{ Substances } & \multicolumn{2}{|c|}{ Limits } \\
\hline & $\begin{array}{l}\text { Ph. Eur. and } \\
\text { USP }\end{array}$ & $\begin{array}{c}\text { Codex Alimentarius } \\
\text { Commission }\end{array}$ \\
\hline alachlor & 0.02 & \\
\hline aldrin and dieldrin (sum of) & 0.05 & \\
\hline azinphos-methyl & 1.0 & 0.5 \\
\hline bromopropylate & 3.0 & \\
\hline chlordane (sum of cis-, trans- and oxythlordane) & 0.05 & \\
\hline chlorfenvinphos & 0.5 & \\
\hline chlorpyrifos & 0.2 & $\begin{array}{l}5.0(\mathrm{~S}) \\
1.0(\mathrm{~F}) \\
1.0(\mathrm{R}) \\
\end{array}$ \\
\hline chlorpyrifos-methyl & 0.1 & $\begin{array}{l}1.0(\mathrm{~S}) \\
0.3(\mathrm{~F}) \\
5.0(\mathrm{R})\end{array}$ \\
\hline cypermethrin (and isomers) & 1.0 & \\
\hline DDT (sum of $p, p^{\prime}-\mathrm{DDE}, o, p^{\prime}-\mathrm{DDT}, p, p^{\prime}-\mathrm{DDT}$ and $p, p^{\prime}-\mathrm{TDE}$ ) & 1.0 & \\
\hline diazinon & 0.5 & $\begin{array}{l}5.0(\mathrm{~S}) \\
0.1(\mathrm{~F}) \\
0.5(\mathrm{R})\end{array}$ \\
\hline dichlorvos & 1.0 & 0.1 \\
\hline dithiocarbamate (as $\mathrm{CS}_{2}$ ) & 2.0 & \\
\hline endosulfan (sum of isomers and endosulfan sulfate) & 3.0 & $\begin{array}{l}1.0(\mathrm{~S}) \\
5.0(\mathrm{~F}) \\
0.5(\mathrm{R})\end{array}$ \\
\hline endrin & 0.05 & \\
\hline ethion & 2.0 & $\begin{array}{l}3.0(\mathrm{~S}) \\
5.0(\mathrm{~F}) \\
0.3(\mathrm{R})\end{array}$ \\
\hline fenitrothion & 0.5 & $\begin{array}{l}7.0(\mathrm{~S}) \\
1.0(\mathrm{~F}) \\
0.1(\mathrm{R})\end{array}$ \\
\hline fenvalerate & 1.5 & \\
\hline fonofos & 0.05 & \\
\hline heptachlor (sum of heptachlor and heptachlorepoxide) & 0.05 & \\
\hline hexachlorobenzene & 0.1 & \\
\hline hexachlorocyclohexane isomers (other than $\gamma$ ) & 0.3 & \\
\hline lindane $(\gamma$-hexachlorocyclohexane $)$ & 0.6 & \\
\hline malathion & 1.0 & $\begin{array}{l}2.0(\mathrm{~S}) \\
1.0(\mathrm{~F}) \\
0.5(\mathrm{R})\end{array}$ \\
\hline methidathion & 0.2 & \\
\hline parathion & 0.5 & $\begin{array}{l}0.1(\mathrm{~S}) \\
0.2(\mathrm{~F}) \\
0.2(\mathrm{R})\end{array}$ \\
\hline parathion-methyl & 0.2 & $\begin{array}{l}5.0(\mathrm{~S}) \\
5.0(\mathrm{~F}) \\
3.0(\mathrm{R})\end{array}$ \\
\hline permethrin & 1.0 & 0.05 \\
\hline phosalone & 0.1 & $\begin{array}{l}2.0(\mathrm{~S}) \\
2.0(\mathrm{~F}) \\
3.0(\mathrm{R})\end{array}$ \\
\hline
\end{tabular}


Table 4 (cont.)

\begin{tabular}{lcc}
\hline piperonyl butoxide & 3.0 & \\
pirimiphos-methyl & 4.0 & $3.0(\mathrm{~S})$ \\
& 3.0 & \\
\hline pyrethrins (sum of) & 3.0 & $0.1(\mathrm{~S})$ \\
quintozene (sum of quitozene, pentachloroaniline and methyl & 1.0 & $0.02(\mathrm{~F})$ \\
pentachlorophenyl sulfide) & & $2.0(\mathrm{R})$ \\
\hline
\end{tabular}

Legend: USP - United States Pharamcopoeia $29^{\text {th }}$ revision and the National Formulary $24^{\text {th }}$ Ed., 2006; Ph. Eur. - European Pharmacopoeia $6^{\text {th }}$ edition, 2007; $S$ - seeds; $F$-fruits; $R$-roots or rhizomes.

control vector-borne diseases such as malaria, and are often applied near agricultural fields. Pesticide residues can drift through the air and contaminate plants in nearby fields (3). Furthermore, medicinal plants are susceptible to insects and diseases just like other crops and may need pesticides for protection (93).

Many studies of pesticide residues in herbal materials have been carried out in different countries. An Egyptian study showed the predominance of malathion in spices and medicinal plants, with the highest mean level $\left(2.19 \mathrm{mg} \mathrm{kg}^{-1}\right)$ detected in chamomile (90). A study of marketed samples of passion flower (Passiflora L.) from Brazil (94) found identified organochlorine pesticide residues (dieldrin, lindane, tetradifon, chlorothalonil, and $\alpha$-endosulfan) at a level of $21 \mu \mathrm{g} \mathrm{kg}^{-1}$ to $71.4 \mu \mathrm{g} \mathrm{kg}^{-1}$. A recent study by Xue et al. (75) identified $\alpha$-BHC, PCNB, $\mathrm{HCH}$, and tecnazene as the most common pesticide residues in 280 samples used in traditional Chinese medicine. Contamination of herbal preparations such as infusions and decoctions has also been reported $(90,95,96)$. The extraction rate of pesticide residues in water primarily depends on their water solubility $(90,95)$. Tewary at al. (95) found that pesticides with low water solubility (organochlorine and synthetic pyrethroid) hardly transferred into decoctions, while polar pesticides (azoles and organophophorous) transferred in considerable amounts. Therefore, the selection of the most suitable pesticide should be based on its leaching potential from particular herbal matrices. According to the European guidelines on quality control of herbal products (97), herbal drugs/ preparations do not have to be tested for pesticide residues in their final dosage form, if they have been tested as raw materials.

Some countries and/or regions have established national requirements for residue limits in herbal materials. The Codex Alimentarius Commission, jointly run by the FAO and WHO, develops international standards on every aspect of food, and one such standard is the maximum residue levels (MRLs) of approved pesticides for spices. MRL means the upper legal concentration limit for a pesticide residue in or on food or feed, based on good agricultural practices and the lowest consumer exposure (88). Table 4 shows a few regional limits for various types of pesticide residues in herbal drugs, with their MRLs adopted by the Codex Alimentarius Commission for spices (3).

A variety of methodologies, such as those described by the WHO guidelines (3), is available for identifying pesticides and other compounds. The principal method for determining pesticide residues is chromatography (capillary gas chromatography, HPLC) coupled with different detectors such as electron capture detector, flame photometric detector, nitrogen-phosphorous detector or mass spectrometry. However, these techniques are not universally applicable. Due to low concentrations to be determined, the compounds of interest have to be separated from the matrix and concentrated to reach the minimum level required by each detector. Separation methods used for this purpose include solid-phase extraction, liquid-liquid extraction, stir bar sorptive extraction, solid-phase microextraction (96), and supercritical fluid extraction (94). Separations may not always be complete, pesticides may decompose or metabolise, and many of the metabolic products are still unknown. Some pesticides are recovered poorly, and some are lost entirely (92). Generally, the method should be adapted to herbal material and modifications may be necessary, especially for samples differing in water content. The European Pharmacopoeia (97) (chapter 2.8.13) includes tests for organochlorine, organophosphorus, and pyrethroid insecticides that are primarily applicable for the analysis of herbal drugs containing less than $15 \%$ of water. These can also be valid for samples with a higher water content, if drying does not significantly affect the pesticide content (67). If exposure to pesticides is unknown, herbal materials 
should be tested at least for the presence of pesticides listed in the European Pharmacopoeia.

Cultivation of some medicinal plants takes years before harvesting and requires treatment with pesticides to reduce pest damage (87). For example, ginseng is cultivated for up to six years, and root damage is common because the plant is highly susceptible to phytopathogens. Quintozene, tolclofosmethyl, endosulfan, and BHC are the most commonly detected pesticide residues in ginseng products. As contamination seems to be inevitable, it is suggested that appropriate pesticide residue removal techniques be applied. One of cost-effective and efficient methods of removing pesticide residues from ginseng extract involves two-phase partition chromatography using soybean oil (99). No significant change in the composition of ginsenosides, the active ingredients of ginseng (Panax ginseng C. A. Mey.), was observed in ginseng extract before and after the oil treatment. In addition, the proposed removal process has no adverse effects on human health and environment. Another suitable method to prevent pesticide residues involves using certain strains of degrading bacteria for bioremediation of contaminated soil (75).

\section{CONCLUSIONS}

The use of herbal products as the first choice in self-treatment of minor conditions continues to expand rapidly across the world. This makes the safety of herbal products an important public health issue. With this review we argue that the quality of herbal products at any production stage directly affects their safety. Recommendations on good agricultural and collection practices in the European and WHO guidelines for raw herbal materials $(3,100,101)$ provide the basis for appropriate quality assurance. Medicinal herbs should not be grown and/or collected in contaminated environments. Any chemicals used to boost growth or protect the crop should be kept to a minimum. Contamination with microbes, toxic elements and agrochemical residues after harvesting should be avoided as much as possible. Effective measures should be taken to prevent the spread of animals (insects and rodents) and micro-organisms brought in with the herbal material, to prevent fermentation or yeast and mould growth, mycotoxin production, and to prevent cross-contamination $(80,101)$. Any treatment to reduce contamination or infestation should be documented. Specifications with suitable methods and justified limits should be available for determination of possible contaminants (102). The processing of herbal materials must observe GMP, with protocols that are similar to those applied in the manufacture of conventional medicines (6). In addition to the published good practice and quality control guidelines for herbal products $(97,103)$, the European Pharmacopoeia provides a valuable collection of monographs on quality requirements for raw herbal materials. Consumer compliance could also decrease the level of microbial contamination in medicinal herb preparations. Some European associations such as Wirtschaftsvereinigung Kräuterund Früchtetee e. V., a member of the European Herbal Infusions Association recommend that a note should be printed on tea-boxes cautioning the consumer : always to boil water and allow to infuse for at least 5 minutes to ensure the safety of use (104).

The same concepts of quality control and quality assurance should apply to herbal products covered by food regulations, as they have the same origin and the same risks of contamination (105). In any case an encompassing and implementable regulatory framework is needed to ensure that herbal products meet quality standards. This in particular refers to testing for and prevention of contamination.

\section{Acknowledgement}

We wish to thank Dario Kremer, $\mathrm{PhD}$ (Pharmaceutical Botanical Garden "Fran Kušan", Faculty of Pharmacy and Biochemistry, University of Zagreb), for checking botanical names.

\section{REFERENCES}

1. Association Européenne des Spécialités Pharmaceutiques Grand Public (AESGP). Economic and Legal Framework for Non-Prescription Medicines. $15^{\text {th }}$ ed. Brussels: AESGP; 2009.

2. World Health Organization (WHO). National policy on traditional medicine and regulation of herbal medicines report of a WHO global survey. Geneva: WHO; 2005.

3. World Health Organization (WHO). WHO guidelines for assessing quality of herbal medicines with reference to contaminants and residue. Geneva: WHO; 2007.

4. World Health Organization (WHO). WHO guidelines on safety monitoring of herbal medicines in pharmacovigilance systems. Geneva: WHO; 2004.

5. Ernst E. Toxic heavy metals and undeclared drugs in Asian herbal medicines. Trends Pharmacol Sci 2002;23:136-9. 
6. World Health Organization (WHO). Supplementary guidelines on good manufacturing practices for the manufacture of herbal medicines. Geneva: WHO; 2006.

7. Chan K. Some aspects of toxic contaminants in herbal medicines. Chemosphere 2003;52:1361-71.

8. Ernst E. Harmless herbs? A review of the recent literature Am J Med 1998;104:170-8.

9. Iten F, Reichling J, Saller R, Unerwunschte Wirkungen und Wechselwirkungen von Phytotherapeutika [Adverse effects and interactions of phytotherapeutic drugs, in German]. Ther Umsch 2002;59:283-91.

10. Directorate for the Quality of Medicines and HealthCare of the Council of Europe (EDQM). Harmonized microbiological methods: 2.6.12.; 2.6.13; 5.1.4., In: European Pharmacopoeia $6^{\text {th }}$ ed. Strasbourg: EDQM; 2007.

11. Borwn JC, Jiang X. Prevalence of antibiotic-resistant bacterial on herbal products. J Good Prot 2008;71:1486-90.

12. Kineman B, Nahikian-Nelms ML, Frazier C. A pilot investigation of the microbial contamination of herbal supplements: A potential risk for immunocompromised populations. HIV Nutrition Update 2002;7:1-9.

13. Hauer T, Jonas D, Dettenkofer M, Daschner FD. Tea as a source of Acinetobacter baumannii ventilator-associated pneumonia? Infect Control Hosp Epidemiol 1999;20:594

14. Wilson C, Dettenkofer M, Jonas D, Daschner FD. Pathogen growth in herbal teas used in clinical settings: A possible source of nosocomial infection? Am J Infect Control 2004:32:117-9.

15. Nakano H, Okabe T, Hashimoto H, Sakaguchi G. Incidence of Clostridium botulinum in honey of various origins. Jap J Med Sci Biol 1990;43:183-95.

16. Schocken-Iturrino RP, Carneiro MC, Kato E, Sorbara JOB, Rossi OD, Gerbasi LER. Study of the presence of the spores of Clostridium botulinum in honey in Brazil. FEMS Immunol Med Microbiol 1999;24:379-82.

17. Bianco MI, Lúquez C, de Jong LIT, Fernández RA. Presence of Clostridium botulinum spores in Matricaria chamomilla (chamomile) and its relationship with infant botulism. Int J Food Microbiol 2008;121:357-60.

18. Martins HM, Martins ML, Dias MI, Bernardo F. Evaluation of microbiological quality of medicinal plants used in natural infusions. Int J Food Microbiol 2001;68:149-53.

19. Koch J, Schrauder A, Alpers K, Werber D, Frank C, Prager R, Rabsch W, Broll S, Feil F, Roggentin P, Bockemühl J, Tschäpe H, Ammon A, Stark K. Salmonella agona outbreak from contaminated aniseed, Germany. Emerg Infect Dis 2005;11:1124-7.

20. Halt M, Klapec T. Microbial populations in medicinal and aromatic plants and herbal teas from Croatia. Ital J Food Sci 2005; 17:349-54.

21. BugnoI A, AlmodovarI AAB, PereiraI TC, Andreoli PintolI TJ, Sabino M. Occurrence of toxigenic fungi in herbal drugs. Braz J Microbiol 2006;37:47-51.

22. Cvetnić Z, Pepeljnjak S. Mycological contamination of stored herbal drugs. Acta Pharm 1999;49:201-9.

23. The European Agency for the Evaluation of Medicinal Products (EMEA). Committee for Proprietary Medicinal Prodcust (CMPM), Committee for Veterinary Medicinal Products (CMVP). Note for guidance on limitations to the use of ethylene oxide in the manufacture of medicinal products [displayed 23 November 2009]. Available at http://www.emea.europa.eu/pdfs/human/qwp/015901en. pdf.
24. Directorate for the Quality of Medicines and HealthCare of the Council of Europe (EDQM). Monograph on herbal drugs (1433). In: European Pharmacopoeia. $6^{\text {th }}$ ed., Strasbourg: EDQM; 2007.

25. Council Directive 86/355/EEC of 21 July 1986 amending Directive 79/117/EEC prohibiting the placing on the market and use of plant protection products containing certain active substances.

26. Mishra BB, Gautam S, Sharma A. Microbial decontamination of tea (Camellia sinensis) by gamma radiation. J Food Sci 2006;71:151-6.

27. Furgeri C, Nunes TCF, Fanaro GB, Souza MFF, Bastos DHM, Villavicencio ALCH. Evaluation of phenolic compounds in maté (Ilex paraguariensis) processed by gamma radiation. Radiat Phys Chem 2009;78:639-41.

28. Al-Bachir M, Al-Adawi MA, Al-Kaid A. Effect of gamma irradiation on microbiological, chemical and sensory characteristics of licorice root product. Radiat Phys Chem 2004;69:333-8.

29. Gašpar Randić Z, Maleš, Ž, Vestermajer G. Tankoslojna kromatografija slobodnih aminokiselina korijena bijelog sljeza (Althaeae radix), izloženog različitim dozama gama zračenja [TLC analysis of free amino acids in Althaeae radix, treated with different $\gamma$-irradiation doses, in Croatian]. Farm Glas 2004;60:1-6.

30. An BJ, Kwak JH, Son JH, Park JM, Lee JY, Jo C, Byun MW. Biological and anti-microbial activity of irradiated green tea polyphenols. Food Chem J 2004;88:549-55.

31. Jo C, Son JH, Lee HJ, Byun MW. Irradiation application of color removal and purification of green tea leave extract. Radiat Phys Chem 2003;66:179-84.

32. Iguera R. Good Agricultural Practice and Good Wild-crafting Practice (oral presentation), 53rd Annual Congress of Society for Medicinal Plant Research (GA), Florence, August 2005 (available at http://www.ga-online.org/files/Florence2005/ WS4_2.pdf)

33. Commonwealth Secretariat. A guide to the European market for medicinal plants and extracts. London: Commonwealth Secretariat; 2001.

34. Arbogast RT, Kendra PE, Mankin RW, McDonald RC. Insect infestation of a botanicals warehouse in north-central Florida. J Stored Prod Res 2002;38:349-63.

35. Ishikawa K, Matsui K, Madarame T, Sato S, Oikawa K, Uchida T. Hepatitis E probably contracted via a Chinese herbal medicine, demonstrated by nucleotide sequencing. $\mathrm{J}$ Gastroenterol 1995;30:534-8.

36. Commission Regulation (EC) No 472/2002 of 12 March 2002 amending Regulation (EC) No 466/2001 setting maximum levels for certain contaminants in foodstuffs. Official Journal of the European Communities L 075 2002;45:18-20.

37. Directorate for the Quality of Medicines and HealthCare of the Council of Europe (EDQM). Determination of aflatoxin B1 in herbal drugs. In: European Pharmacopoeia. Chapter 2. 8. 18. $6^{\text {th }}$ ed. Strasbourg: EDQM; 2007.

38. Directorate for the Quality of Medicines and HealthCare of the Council of Europe (EDQM). Determination of ochratoxin A in herbal drugs. In: European Pharmacopoeia. Chapter 2. 8. 22. $6^{\text {th }}$ ed. Strasbourg: EDQM; 2007.

39. Kabelitz L, Sievers H. Contaminants of medicinal and food herbs with a view to EU regulations. Innovations Food Technol 2004:25-7. 
40. Romagnoli B, Menna V, Gruppioni N, Bergamini C. Aflatoxins in spices, aromatic herbs, herb-teas and medicinal plants marketed in Italy. Food Control 2007;18:697-701.

41. Fuat Abd Razak M, Aidoo KE, Candlish AGG. Mixed herbal drugs: inhibitory effect on growth of the endogenous mycoflora and aflatoxin production. Mycopathologia 2009; 167:273-86.

42. International Agency for Research on Cancer (IARC). Ochratoxin A some naturally occurring substances: Food items and constituents, heterocyclic aromatic amines and mycotoxins. In: Monographs on the evaluation of carcinogenic risk to humans. Vol. 56. Lyon: IARC; 1993. p. 489-52.

43. Leslie JF, Bandyopadhyay R, Visconti A, editors. Mycotoxins, detection methods, management, public health and agricultural trade. Oxfordshire: $\mathrm{CAB}$ International; 2008.

44. Pitt JI. Toxigenic fungi and mycotoxins. Br Med Bull 2000;56:184-92.

45. Bresch H, Urbanek M, Nusser M. Ochratoxin A in food containing liquorice. Nahrung 2000;44:276-8.

46. Majerus P, Max M, Klaffke M, Palavinskas R. Ochratoxin A in Sübholz, Lakritze und daraus hergestellten Erzeugnissen [Ochratoxin A in liquorice root, sweet liquorice and their manufactured products, in German]. Deustch LebensmRundsch 2000;96:451-4.

47. Arino A Herrera M, Estopanan G, Juan T. High levels of ochratoxin A in licorice and derived products. Int J Food Microbiol 2007;114:366-9.

48. Herrera M, Herrera A, Arino A. Estimation of dietary intake of ochratoxin A from liquorice confectionery. Food Chem Toxicol 2009;47:2002-6.

49. International Agency for Research on Cancer (IARC). Summaries and evaluations fumosin B1. In: Monographs on the evaluation of carcinogenic risk to humans. Vol. 82 . Lyon: IARC; 2002. p. 301.

50. Omurtag GZ, Yazicioğlu D. Determination of fumonisins $\mathrm{B}_{1}$ and $\mathrm{B}_{2}$ in herbal tea and medicinal plants in Turkey by high-performance liquid chromatography. J Food Prot 2004;67:1782-6.

51. Sewram V, Shephard GS, van der Merwe L, Jacobs TV. Mycotoxin contamination of dietary and medicinal wild plants in the Eastern Cape Province of South Africa. J Agric Food Chem 2006;54:5688-93.

52. Santos L, Marín S, Sanchis V, Ramos AJ. Screening of mycotoxin multicontamination in medicinal and aromatic herbs sampled in Spain. J Sci Food Agric 2009;89:1802-7.

53. Mazzanti G, Battinelli L, Daniele C, Costantini S, Ciaralli L, Evandri MG. Purity control of some Chinese crude herbal drugs marketed in Italy. Food Chem Toxicol 2008;46:30437.

54. Herbal drugs. Monograph 1433. Pharmeuropa 2008;20(2):3023.

55. Commission Regulation (EC) No. 629/2008 amending Regulation (EC) No. 1881/2006 of 19 December 2006 setting maximum levels for certain contaminants in foodstuffs. Official Journal of the European Union L 173 2008;51:6-9.

56. International Programme on Chemical Safety (IPCS). JECFA glossary of terms [displayed 15 July 2009]. Available at http://www.who.int/ipcs/food/jecfa/glossary.pdf.
57. World Health Organization (WHO). Evaluation of certain food additives and contaminants. Twenty-second Report of the Joint FAO/WHO Expert Committee on Food Additives. Technical Report Series 631. Geneva: WHO; 1978.

58. World Health Organization (WHO). Evaluation of certain food additives and contaminants. Thirty-third Report of the Joint FAO/WHO Expert Committee on Food Additives. Technical Report Series 776. Geneva: WHO; 1989.

59. World Health Organization (WHO). Evaluation of certain food additives and contaminants. Fifty-third Report of the Joint FAO/WHO Expert Committee on Food Additives. Technical Report Series 896. Geneva: WHO; 2000.

60. JECFA. Summary of Evaluation Performed by the Joint FAO/WHO Expert Committee on Food Additives (JECFA). $64^{\text {th }}$ meeting. 8.-17. Feb 2005. Rome, Italy [displayed 15 July 2009]. Available at ftp://ftp.fao.org/es/esn/jecfa/jecfa64_ summary.pdf.

61. Caldas ED, Machado LL. Cadmium, mercury and lead in medicinal herbs in Brazil. Food Chem Toxicol 2004;42:599603.

62. Donkin SG, Ohlson DL, Teaf CM. Properties and effects of metals. In: Williams PL, James RC, Roberts SM, editors. Principles of Toxicology: Environmental and Industrial Applications. New York: John Wiley and Sons Inc.; 2000. p. $325-45$.

63. Obi E, Akunyili DN, Ekpo B, Orisakwe OE. Heavy metal hazards of Nigerian herbal remedies. Sci Total Environ 2006;369:35-41.

64. World Health Organization (WHO). Evaluation of certain food additives and contaminants. Twenty-sixth Report of the Joint FAO/WHO Expert Committee on Food Additives. Technical Report Series 683. Geneva: WHO; 1982.

65. Jyoti B, Nair S, Kakkar P. Heavy metal accumulation in medicinal plants collected from environmentally different sites. Biomed Environ Sci 2008;21:319-24.

66. Slaveska R, Spirevska I, Stafilov T, Ristov T. The content of trace metals in some herbal teas and their aqueous extracts. Acta Pharm 1998;48:201-9.

67. Directorate for the Quality of Medicines and HealthCare of the Council of Europe (EDQM). European Pharmacopoeia. $6^{\text {th }}$ ed. Strasbourg: EDQM; 2007.

68. Gasser U, Klier B, Kühn AV, Steinhoff B. Current findings on the heavy metal content in herbal drugs. Pharmeur Sci Notes 2009;1:37-49.

69. Arpadjan S, Çelik G, Taskesen S, Güçer S. Arsenic, cadmium and lead in medicinal herbs and their fractionation. Food Chem Toxicol 2008;46:2871-5.

70. Koh HL, Woo SO. Chinese proprietary medicine in Singapore. Regulatory control of toxic heavy metals and undeclared drugs. Drug Safety 2000;23:351-62.

71. Gogtay NJ, Bhatt HA, Dalvi SS, Kshirsagar NA. The use and safety of non-allopathic Indian medicines. Drug Safety 2002;25:1005-19.

72. Ernst E, Coon JT. Heavy metals in traditional Chinese medicines: a systematic review. Clin Pharmacol Ther 2001;70:497-504.

73. Itankar PR, Sakharkar PR, Chandewar AV, Patil AT. Estimation of arsenic content in some Ayurvedic formulations. Hamdard Medicus 2001;19:95-7.

74. Saper RB, Kales SN, Paquin J, Burns MJ, Eisenberg DM, Davis RB, Phillips RS. Heavy metal content of ayurvedic herbal medicine products. JAMA 2004;292:2868-73. 
75. Xue J, Liu D, Chen S, Liao Y, Zou Z. Overview on external contamination sources in traditional Chinese medicines. Mode Tradit Chin Med Mater Med 2008;10:91-6.

76. van Vonderen MGA, Klinkenberg-Knot EC, Craanen ME Severe gastrointestinal symptoms due to lead poisoning from Indian traditional medicine. Am J Gastroenterol 2000;95:1591-2.

77. Ibrahim AS, Latif AH. Adult lead poisoning from a herbal medicine. Saudi Med J 2002;23:591-3.

78. Tait PA, Vora A, James S, Fitzgerald DJ, Pester BA. Severe congenital lead poisoning in a preterm infant due to a herbal remedy. Med J Australia 2002;177:193-5.

79. Lee L, Bebb G. A case of Bowen's disease and small-cell lung carcinoma: long-term consequences of chronic arsenic exposure in Chinese traditional medicine. Environ Health Perspect 2005;113:207-10.

80. Khan IA. Issues related to botanicals. Life Sci 2006;78:20338.

81. Lekouch N, Sedki A, Nejmeddine A, Gamon S. Lead and traditional Moroccan pharmacopoeia. Sci Total Environ 2001;280:39-43.

82. Kalny P, Fijalek Z, Daszczuk A, Ostapczuk P. Determination of selected microelements in polish herbs and their infusions. Sci Total Environ 2007;381:99-104.

83. Tumir H. Polumetali i metali u dodacima prehrani i homeopatskim pripravcima [Metalloids and Metals in Food Supplements and Homeopathic Products, in Croatian]. [MSc thesis]. Zagreb: Faculty of Pharmacy and Biochemistry, University of Zagreb; 2008.

84. Arce S, Cerutti S, Oisina R, Gomez MR, Martínes LD. Determination of metal content in valerian root phytopharmaceutical derivatives by atomic spectrometry. J AOAC Int 2005;88:221-5.

85. García-Rico L, Leyva-Perez J, Jara-Marini ME. Content and daily intake of copper, zink, lead, cadmium and mercury from dietary supplements in Mexico. Food Chem Toxicol 2007;45:1599-605.

86. Britt JK. Properties and effects of pesticides. In: Williams PL, James RC, Roberts SM, editors. Principles of Toxicology: Environmental and Industrial Applications. New York: John Wiley and Sons Inc.; 2000. p. 345-66.

87. Ling YC, Teng HC, Cartwright C. Supercritical fluid extraction and clean-up of organochlorine pesticides in Chinese herbal medicine. J Chromatogr A 1999;835:14557.

88. Regulation (EC) No 396/2005 of the European Parliament and of the Council of 23 February 2005 on maximum residue levels of pesticides in or on food and feed of plant and animal origin and amending Council Directive 91/414/EEC. Official Journal of the European Union L 070 2005;48:1-16.

89. Barriada PM, Concha GE. Microwave-assisted extraction versus Soxhlet extraction in the analysis of 21 organochlorine pesticides in plants. J Chromatogr A 2003;1008:115-22.

90. Abou-Arab AAK, Abou Donia MA. Pesticide residues in some Egyptian spices and medicinal plants as affected by processing. Food Chem 2001;72:439-45.
91. Xue J, Hao L, Peng F. Residues of 18 organochlorine pesticides in 30 traditional Chinese medicines. Chemosphere 2008;71:1051-5.

92. Hajou RMK, Afifi FU, Battah AH. Comparative determination of multi-pesticide residues in Pimpinella anisum using two different AOAC methods. Food Chem 2004;88:469-78.

93. de Smet PAGM, Keller K, Hänsel R, Chandler RF. Adverse effects of herbal drugs. $1^{\text {st }}$ ed. Berlin, Heidelberg: Springer; 1992.

94. Zuina VG, Yariwakea JH, Bicchi C. Fast supercritical fluid extraction and high-resolution gas chromatography with electron-capture and flame photometric detection for multiresidue screening of organochlorine and organophosphorus pesticides in Brazil's medicinal plants. J Chromatogr A 2003;985:159-66.

95. Tewary DK, Kumar V, Shanker A. Leaching of pesticides in herbal decoction. Chem Health Safe 2004;11:25-9.

96. Campillo N, Peñalver R, Hernández-Córdoba M. Pesticide analysis in herbal infusions by solid-phase microextraction and gas chromatography with atomic emission detection. Talanta 2007;71:1417-23

97. European Medicines Agency (EMEA). Guideline on specifications: test procedures and acceptance criteria for herbal substances, herbal preparations and herbal medicinal products / traditional herbal medicinal products. CPMP/ QWP/2820/00 Rev 1. London: EMEA; 2006.

98. The United States Pharmacopoeial (USP) Convention. The United States Pharmacopoeia $29^{\text {th }}$ Revision and the National Formulary $24^{\text {th }}$ Edition. Rockville (USA): USP; 2006.

99. Sohn S-H, Kim S-K, Kang H-G, Wee J-J. Two-phase partition chromatography using soybean oil eliminates pesticide residues in aqueous ginseng extract. J Chromatogr A 2004;1042:163-8.

100. World Health Organization (WHO). WHO guidelines on good agricultural and field collection practices (GACP) for medicinal plants. Geneva: WHO; 2003.

101. European Medicines Agency (EMEA). Guideline on Good Agricultural and Collection Practice for starting materials of Herbal Origin. EMEA/HMPC/246816/05. London: EMEA; 2006.

102. EudraLex. The Rules Governing Medicinal Products in the European Union, Annex 7 Manufacture of Herbal Medicinal Products. Volume 4. Brussels: European Commission; 2008.

103. European Medicines Agency (EMEA). Guideline on quality of herbal medicinal products/traditional herbal medicinal products. CPMP/QWP/2819/00 Rev 1. London: EMEA; 2006.

104. Kolb N. Microbiological status of untreated herbal materials. Deutsche Lebensmittel-Rundschau 1999;95:263-9.

105. Bast A, Chandler RF, Choy PC, Delmulle LM, Gruenwald J, Halkes SBA, Keller K, Koeman JH, Peters P, Przyrembel H, de Ree EM, Renwick AG, Vermeer ITM. Botanical health products, positioning and requirements for effective and safe use. Environ Toxicol Pharmacol 2002;12:195-211. 


\section{Sažetak}

\section{ONEČIŠĆENJA U LJEKOVITOM BILJU I BILJNIM PROIZVODIMA}

Ljekovito bilje i biljni proizvodi već tisućljećima nalaze široku primjenu u različitim sustavima tradicionalnog liječenja. Stoga je njihova neškodljivost, ponajprije uvjetovana kakvoćom biljne sirovine, od izuzetne važnosti za javno zdravstvo. Od mogućih čimbenika koji utječu na kakvoću ljekovitog bilja i biljnih proizvoda ovaj pregledni rad osvrće se na najčešće prisutna biološka (mikroorganizmi) i kemijska onečišćenja (mikotoksini, toksični elementi poput teških metala te ostaci pesticida). S ciljem postizanja ujednačenih standarda kakvoće te osiguranja sigurnosti primjene biljnih proizvoda od vitalne su važnosti zakonski propisi koji moraju u odgovarajućim regulatornim okvirima obuhvatiti ovu skupinu proizvoda s naglaskom na sprječavanju i ispitivanju njihovih mogućih onečišćenja.

KLJUČNE RIJEČI: biljni lijek, mikotoksini, mikroorganizmi, pesticidi, teški metali

CORRESPONDING AUTHOR:

Ivan Kosalec, $\mathrm{PhD}$

Faculty of Pharmacy and Biochemistry, University of Zagreb

A. Kovačića 1, HR-10000 Zagreb, Croatia

E-mail: ikosalec@pharma.hr 